Lee, J.M.; Hemmingson, N.R.; Minneé, E.M.K ; Clark, C.E.F. 2015. Management strategies for chicory (Cichorium intybus) and plantain (Plantago lanceolata): impact on dry matter yield, nutritive characteristics and plant density. Crop and Pasture Science 66: 168-183.

Malcolm, B.J.; Cameron, K.C.; Di, H.J.; Edwards, G.R.; Moir, J.L. 2014. The effect of four different pasture species compositions on nitrate leaching losses under high N loading. Soil Use and Management 30:58-68. high $\mathrm{N}$; Chapman, D.; Moir, J.; Cameron, K. 2017. Herbage dry matter (DM) yield and nitrogen concentration of grass, legume and herb species grown at differen nitrogen fertiliser rates under irrigation Animal Production Science 57: 1283-1288. https://dio.org/ 10.1071/AN16455.

McKenzie, B.A.; Kemp, P.D.; Moot, D.J.; Matthew, C.; Lucas, R.J. 1999. Environmental effects on plant growth and development. pp. 29-44. In: New Zealand pasture and crop science. Eds. White, J.; Hodgson, J. Oxford University Press: Auckland, New Zealand.

Ministry for the Environment, 2014. National policy statement for freshwater management. In: ME 1244 Ed. Ministry for the Environment. Wellington.

Minneé, E.; Clark, C.; Clark, D. 2013. Herbage production from five grazeable forages. Proceedings of the New Zealand Grassland Association 75: 245250.

Moorby, J. 2014. Relationship between the composition of fresh grass-based diets and the excretion of dietary nitrogen from dairy cows. The Future of European Grasslands 50: 686-689.
Moore, K.; Moser, L.E.; Vogel, K.P.; Waller, S.S.; Johnson, B.; Pedersen, J.F. 1991. Describing and quantifying growth stages of perennial forage grasses. Agronomy Journal 83: 1073-1077.

Moot, D.J.; Brown, H.E.; Teixeira, E.I.; Pollock, K.M. 2003. Crop growth and development affect seasonal priorities for lucerne management Legumes for dryland pastures. Grassland Research and Practice Series 11: 18-19.

Peyraud, J.L. Astigarraga, L. 1998. Review of the effect of nitrogen fertilization on the chemical composition, intake, digestion and nutritive value of fresh herbage: consequences on animal nutrition and $\mathrm{N}$ balance. Animal Feed Science and Technology 72 : 235-259.

Powell, A.M.; Kemp, P.D.; Jaya, I.K.D.; Osborne, M.A. 2007. Establishment, growth and development of plantain and chicory under grazing. Proceedings of the New Zealand Grassland Association 69:41-45.

Rawnsley, R.P.; Donaghy, D.J.;

P.A. 2002. Changes in the physology a quality of cocksfoot (Dactylis glomerata L.) during regrowth. Grass and Forage Science 57: 203-211.

Silsbury, J. 1970. Leaf growth in pasture grasses. Tropical Grasslands 4: 17-36.

van Loo, E. 1992. Tillering, leaf expansion and growth of plants of two cultivars of perennial ryegrass grown using hydroponics at two water potentials. Annals of Botany 70: 511-518.

Woods, R.; Cameron, K.; Edwards, G.; Di, H.; Clough, T. 2016. Effects of forage type and gibberellic acid on nitrate leaching losses. Soil Use and Management 32: 565-572.

\section{Further field evaluation of the controlled release nitrogen fertiliser} Smartfert ${ }^{\circledR}$

D.C. EDMEADES and R.M. McBRIDE agKnowledge Ltd, PO Box 9147 Hamilton 3240, New Zealand

doug.edmeades@agknowledge.co.nz

\section{Abstract}

Five field trials were conducted over 2 years in which the effects of single applications of different rates of a controlled release nitrogen $(\mathrm{N})$ fertiliser, Smartfert, on pasture production and pasture $\mathrm{N}$ concentration were measured, relative to the same rates of SustaiN. The 2016 trials also compared multiple applications of SustaiN with a single application of Smartfert. Pasture responses to SustaiN relative to the control generally occurred within the first one to three harvests following application and then declined and became negative in the later harvests. The pasture responses to Smartfert developed more slowly and were greatest after the third harvest. In terms of total production significant $(\mathrm{P}<0.05)$ responses to Smartfert relative to the same rate of $\mathrm{N}$ applied as SustaiN occurred in three trials. SustaiN significantly increase pasture production at one site relative to Smartfert. In three trials pasture production from single applications of Smartfert applied at 100 $\mathrm{kgN} / \mathrm{h}$ a were the same and in one case better $(\mathrm{P}<0.05)$ than three consecutive applications of $33 \mathrm{~kg} \mathrm{~N} / \mathrm{ha}$ of SustaiN. The soluble N fertilisers, urea and SustaiN, elevated the mixed-pasture $\mathrm{N}$ concentration relative to control and to Smartfert in the first harvest following application. The nitrogen use efficiency (NUE, kg DM/ $\mathrm{kg}$ fertiliser $\mathrm{N}$ applied) of Smartfert was significantly greater $(\mathrm{P}<0.05)$ than for SustaiN in two trials.

Keywords: fertiliser, nitrogen, nitrogen use efficiency, pasture, Smartfert, urea, SustaiN

\section{Introduction}

New Zealand uses about 350000 tonnes of fertiliser N annually (Fertiliser Matters 2010) most of which is applied in a readily available, water-soluble form, such as urea, ammonium sulphate or diammonium phosphate. The $\mathrm{N}$ in such products is subject to losses to the environment via: volatilisation (ammonium), denitrification (nitrogen and nitrous oxides gases), leaching (nitrate) and runoff (ammonium and nitrate). leaching (nitrate) and runoff (ammonium and nitrate). There are international (Our Nutrient World 2013)
and national (Ministry of Primary Industries 2013) initiatives to increase nitrogen $(\mathrm{N})$ use efficiency (NUE), driven by both economic and environmental considerations and concerns. There are many ways to define and hence measure NUE and de Klein et al. (2016) have usefully defined three broad categories:
Crop NUE, Animal NUE and Whole farm NUE. They defined the Crop NUE as the crop dry matter (DM) per unit of $\mathrm{N}$ input of which fertiliser NUE $(\mathrm{kg} \mathrm{DM} / \mathrm{kg}$ fertiliser $\mathrm{N}$ applied) is a subset.

Edmeades (2015) reported on the evaluation of Smartfert, a controlled release nitrogen fertiliser which, in three field trials, increased the NUE $(\mathrm{kg} D M / \mathrm{kg} \mathrm{N}$ applied) in pastures by between $5-50 \%$, depending on the site and the rate of application.

In this paper the results from five further field trials are discussed focussing on the potential economic and environmental benefits and the NUE $(\mathrm{kg} \mathrm{DM} / \mathrm{kg}$ fertiliser $\mathrm{N}$ applied) of Smartfert.

\section{Methods}

\section{Field Trials}

作 been described earlier (Edmeades 2015). Mixedpasture samples were collected at each harvest from these trials, either on a per plot basis (Taupo) or bulked over replicates (Rotorua and Northland) and have been analysed for total nitrogen concentration ( $\mathrm{N} \%$ ). These results are reported in this paper.

Five further field trials were conducted, two in 2015 and further three in 2016. All these trials (mowing with clippings removed, plot size $2 \times 6 \mathrm{~m}$ ) were on clover-based pastures using standard management and measurements techniques (Lynch 1966). The trial designs and treatments, however, were changed between years driven largely by commercial rather than reated with a urease inhibitor), a proprietary product from Ballance AgriNutrients Ltd was used as the standard for comparison with Smartfert.

The two 2015 trials, one each in Northland and Rotorua, comprised six replicates of seven treatments: control, SustaiN $30 \mathrm{~kg}$ N/ha (SustaiN30), SustaiN (Smartfert30), Smartfert $60 \mathrm{~kg} \mathrm{~N} / \mathrm{ha} / \mathrm{yr}$ (Smartfert60) and a 50.50 mix of SustaiN and Smartfert applied at 30 or $60 \mathrm{~kg} \mathrm{~N} / \mathrm{ha}$. The treatments were applied once at 30 or $60 \mathrm{~kg} \mathrm{~N} / \mathrm{ha}$. The treatments were applied once at the commencement of the trials in September and the production measurements terminated after 6 harvests in either January or February. Pasture DM ( $\mathrm{kg} \mathrm{DM} / \mathrm{ha})$ was measured on a per plot basis, and for the Rotorua measured on samples bulked by treatments. scientific considerations. For example, SustaiN (ure $60 \mathrm{~kg} \mathrm{~N} / \mathrm{ha}$ (SustaiN60), Smartfert $30 \mathrm{~kg} \mathrm{~N} / \mathrm{ha}$ 

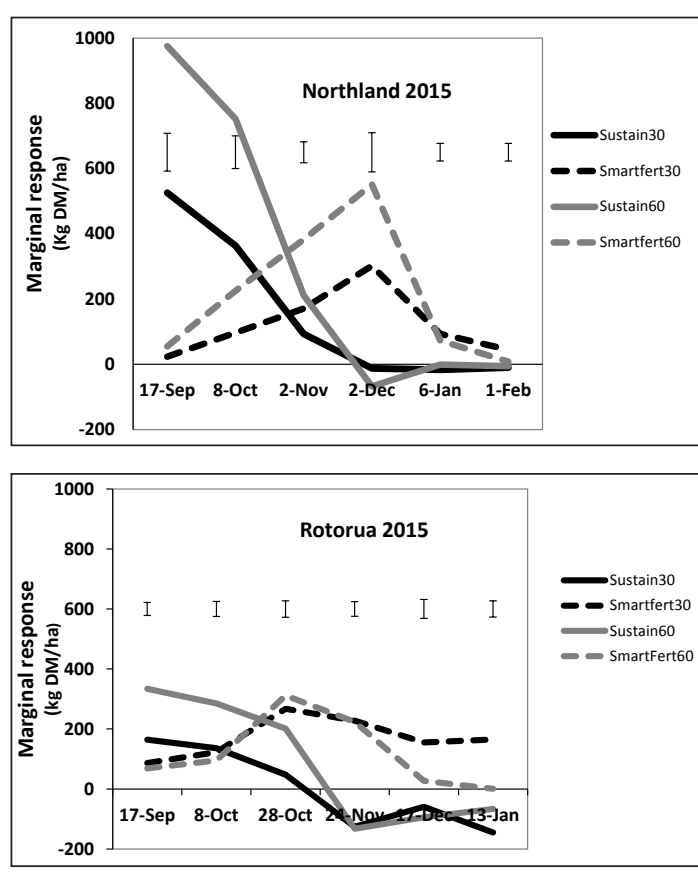

Figure 1 Marginal pasture responses (kg DM/ha) relative to control over time after single applications of two ha) in two trials in 2015. Vertical bars are SED's.

Three further trials in Northland, Rotorua and Canterbury were commenced in early spring (July or August) in 2016. The number of replications was increased to 10 and each trial comprised seven treatments: control, SustaiN $30 \mathrm{~kg} \mathrm{~N} / \mathrm{ha}$ (SustaiN30), SustaiN 100 $\mathrm{kg} \mathrm{N} / \mathrm{ha}$ applied in 3 equal applications (SustaiN $100 \times$ 3), Smartfert $30 \mathrm{~kg} \mathrm{~N} / \mathrm{ha}$ (Smartfert30), Smartfert 100 $\mathrm{kg} \mathrm{N} / \mathrm{ha}$ applied once at the commencment of the tria (Smartfert100), and a 30:70 mix of SustaiN and Smartfert applied once at 30 or $100 \mathrm{~kg} \mathrm{~N} / \mathrm{ha}$. Six harvests were ppled on a 30 or 100 kg Nerin taken on each trial which were terminated between late $(\mathrm{kg} \mathrm{DM} / \mathrm{ha})$ was measured on a plot basis and mixedpasture $\mathrm{N}$ concentrations were measured on a bulked treatment basis. The results from the mixed-fertilise treatments in 2015 and 2016 are not discussed in this paper because they are predictable from the proportion of the two types of fertiliser present in the mixes.
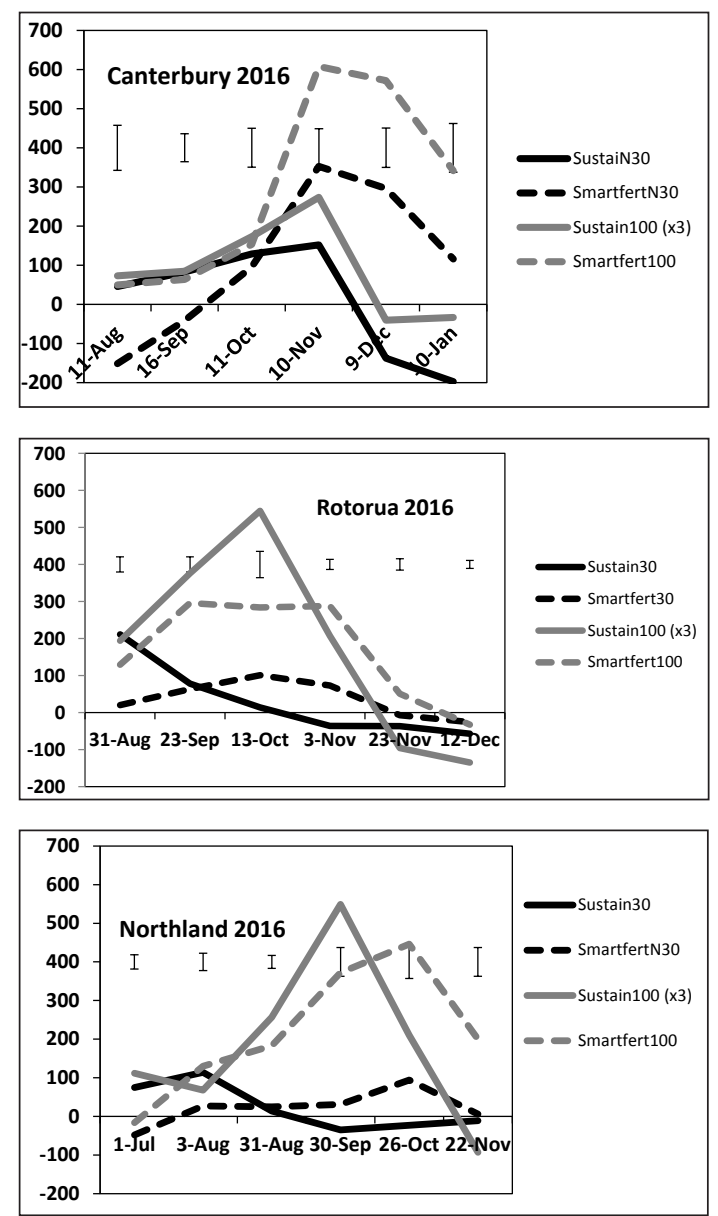

Figure 2 Marginal pasture responses (kg DM/ha) relative to control over time after single applications of Sustain, Smartfert (30 kg N/ha) and Smartfert (100 $\mathrm{kg} \mathrm{N} / \mathrm{ha})$ and split applications of Sustain $(3 \times 33$ $\mathrm{kg} \mathrm{N} / \mathrm{ha}$ ) in three trials in 2016. Vertical bars are

\section{Results and Discussion}

Pasture DM

The total pasture production $(\mathrm{kg} \mathrm{DM} / \mathrm{ha})$ over the duration of each trial from each treatment in the two 2015 and the three trials in 2016 are given in Tables 1 and 2, respectively. The marginal (relative to the control) pasture production responses at each harvest date are presented in Figure 1 (2015 trials) and Figure 2 (2016 trials).

Table 1 Total pasture production ( $\mathrm{kg} \mathrm{DM} / \mathrm{ha}$ ) on two sites in 2015 after treatment with single applications of two rates ( $30 \mathrm{~kg} \mathrm{~N} / \mathrm{ha}$ and $60 \mathrm{~kg} \mathrm{~N} / \mathrm{ha}$ ) of Sustain or Smartfert.

\begin{tabular}{lcccccc}
\hline Site & Control & Sustain 30 & Smartfert 30 & Sustain60 & Smartfert 60 & SED \\
\hline Northland & 2937 & 3881 & 3669 & 4803 & 4231 & 183 \\
Rotorua & 6241 & 6140 & 7087 & 6712 & 6960 & 306 \\
\hline
\end{tabular}
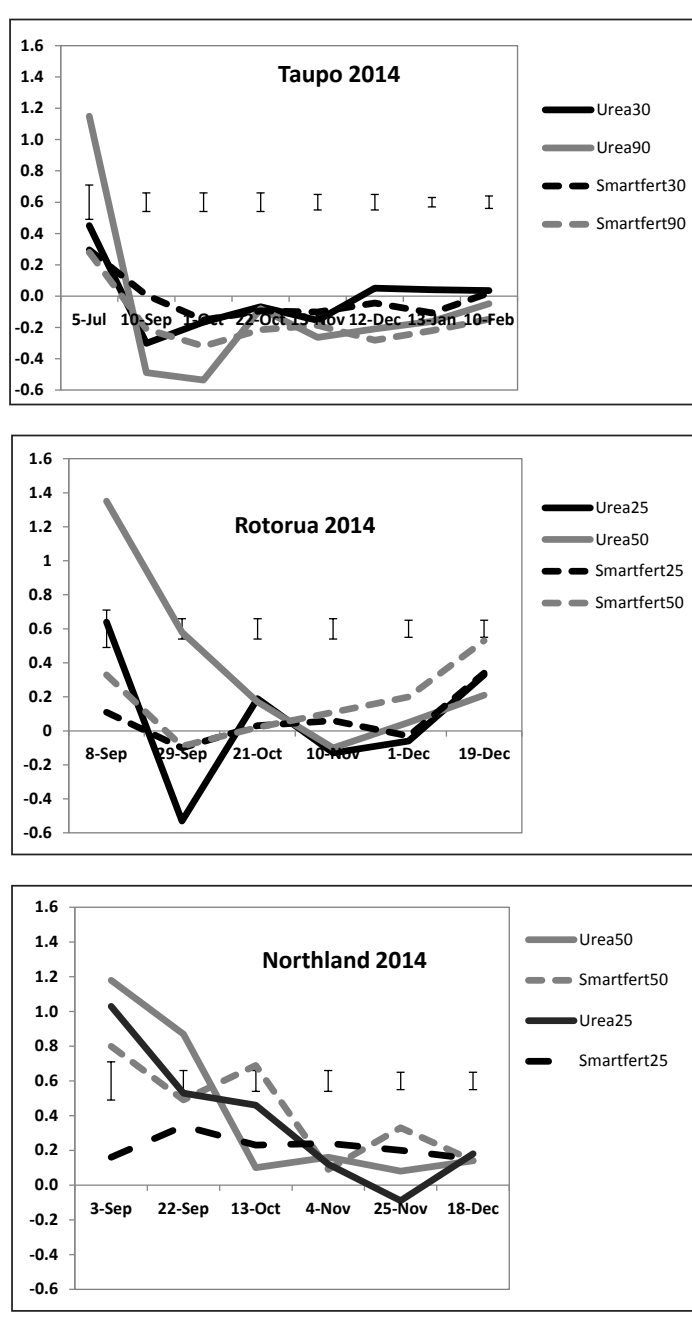

Figure 3 Marginal pasture nitrogen concentrations (No) relative to control over time after single (2) $50 \mathrm{~kg}$ Nha) in three trials in 2014 . are the SED's. These were measured in the Taupo trial where the \% $\mathrm{N}$ was measured on a per plot basis and it is assumed that the same variability applies to the other two trials in which the $\% \mathrm{~N}$ was measured on samples bulked by treatment.

Table 2 Total pasture production ( $\mathrm{kg} \mathrm{DM} / \mathrm{ha}$ ) after treatment with single applications of Sustain or Smartfert at (100 applications on three sites in 2016.

\begin{tabular}{lcccccc}
\hline Site & Control & Sustain $\mathbf{3 0}$ & Smartfert 30 & Sustain 100 $(\mathbf{x} 3)$ & Smartfert 100 & SED \\
\hline Northland & 5141 & 5277 & 5274 & 6246 & 6456 & 263 \\
Rotorua & 3707 & 3881 & 3931 & 4799 & 4723 & 164 \\
Canterbury & 5824 & 5897 & 6491 & 6353 & 7610 & 442 \\
\hline
\end{tabular}

The control DM yields indicate that the most and least Troductive sites were Rotorua (2015) and Northlan (2015), respectively, and the most responsive site to soluble N (SustaiN) was the Northland (2015) site. The Rotorua (2015) and the Northland (2016) sites were the least responsive sites to soluble $\mathrm{N}$ (SustaiN). At comparable rates of $\mathrm{N}$ application, SustaiN and Smartfert gave similar overall yields, but significant $(\mathrm{P}<0.05)$ responses to Smartfert relative to the same rate of N applied as SustaiN were recorded in Rotorua (2015) at the $30 \mathrm{~kg} \mathrm{~N} / \mathrm{ha}$ rate and in Canterbury (2016) at the $100 \mathrm{~kg} \mathrm{~N} / \mathrm{ha}$ rate. At the Northland site in 2015 the yield from SustaiN was greater $(\mathrm{P}<0.05)$ than from Smartfert when compared at $60 \mathrm{~kg} \mathrm{~N} / \mathrm{ha}$.

Pasture responses to SustaiN relative to control generally occurred within the first one to three harvests and then declined, whereas the pasture responses to Smartfert developed more slowly and were greates after the third harvest (Figures 1,2). This pattern was similar to the results from three pasture trials reported earlier (Edmeades 2015) in which urea was compared Edmeades \& McBride (2012) that there is little difference in the agronomic performance of urea and SustaiN.

A further feature of these results is the development several months after application of depressions in pasture growth relative to the control from SustaiN treated pastures. This trend was also apparent in the earlier trials with urea (Edmeades 2015) and has been reported elsewhere (Feyter et al. 1985; Carlson et al 2017). Feyter et al. (1985) showed that depressions in pasture production due to urea developed over time and could be attributed the reduced clover content in the urea treated pastures. In the current trials, pasture responses to Smartfert also declined over time but did not become negative, at least over the trial duration.

The 2016 trials compared the effect of Smartfert applied once at $100 \mathrm{~kg} \mathrm{~N} / \mathrm{ha}$ with three equal pplications of $33 \mathrm{~kg} \mathrm{~N} / \mathrm{ha}$ as SustaiN. In the Canterbury trial, Smartfert applied once at $100 \mathrm{~kg} \mathrm{~N} / \mathrm{ha}$ outyielded the production $(\mathrm{P}<0.05)$ from multiple applications of Sustain, but in the other two trials this difference was not significant. This is consistent with the results from the 2014 Taupo trial reported earlier (Edmeades 2015). These results have important economic and farm management implications.

Current advice on soluble fertiliser N use (Robets \& Morton 2004) is based on the knowledge that pasture to Smartfert, consistent with the conclusion reached by 442 
responses to soluble $\mathrm{N}$ fertiliser, such as urea and SustaiN last about 4-6 weeks, advice consistent with the results in Figures 2 and 3. Thus, some dairy farmers apply sequential applications of 20-30 kg N/ha every 4-6 weeks. The current results (Table 2) indicate that the same pasture production can be achieved with single large application of Smartfert, thus reducing on-farm application costs. Some sheep and beef farmers apply soluble $\mathrm{N}$ fertiliser N 4-6 weeks before likely feed shortfalls, such as during lambing. These results show that the additonal pasture growth from SmartFert is spread over a longer time and hence the timing of application is not so important, allowing for greater flexibility.

\section{Mixed pasture $\mathrm{N}$ concentration}

The mixed-pasture $\mathrm{N}$ concentrations, expressed as the difference from the control, for the seven trials in which this parameter was measured, including the three trials completed in 2014, are presented in Figures 3, 4 and 5. In the 2014 and the 2015 trials the soluble $\mathrm{N}$ fertilisers, urea and SustaiN, significantly increased the mixedpasture $\mathrm{N}$ concentrations in the first harvest relative to the control and relative to Smartfert. This effect was no apparent in the three 2016 trials.

Most of the nitrate $\mathrm{N}$ leached from intensive dairy systems originates from the urine patch (Shepherd \& Lucci 2013) and it has been shown that there is an almost linear relationsip between $\mathrm{N}$ intakes and excreted urinary N (Dijkstra et al. 2013). There are two factors which affect $\mathrm{N}$ intake - the amount of DM consumed and the $\mathrm{N}$ concentration of the DM (Shepherd \& Lucci 2013). They calculated that modest increases in pasture $\mathrm{N}$ concentration of $5-10 \%$ could increase $\mathrm{N}$ leaching by $1-5 \mathrm{~kg} \mathrm{~N} / \mathrm{ha}$.

Based on the 2014 and 2015 results (Figure 3) the

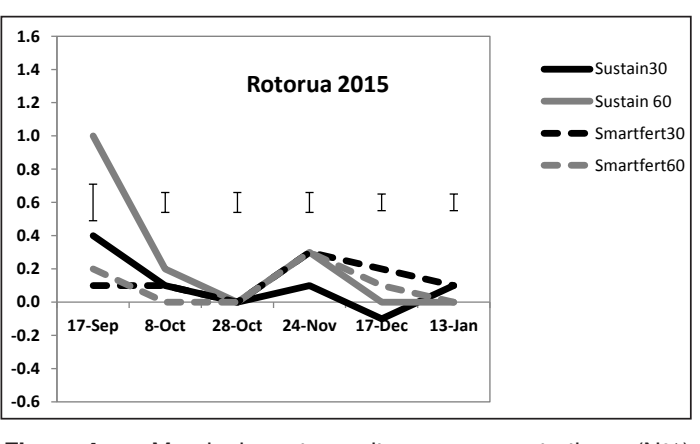
relative to control over time after single applications of two rates of Sustain and Smartfert (30 and $60 \mathrm{~kg}$ N/ha) on a trial in 2015. Vertical bars are the SED's assuming the same variability as measured in the
Taupo 2014 trial.

average difference in pasture $\mathrm{N}$ concentration in the first harvest following application of either Smartfert $\mathrm{N}$ or soluble fertiliser $\mathrm{N}$ ranges from $12-18 \%$. This suggests that replacing soluble $\mathrm{N}$ fertiliser with Smartfert may reduce $\mathrm{N}$ leaching by $5-10 \mathrm{~kg} \mathrm{~N} / \mathrm{ha}$ per grazing (M. Shepherd pers. comm.). This calculation assumes that the pasture $\mathrm{N}$ concentration for Smartfert was $4.2 \%$, that the pasture on offer was 1000-1500 kg DM/ha and production by about $200 \mathrm{~kg} \mathrm{DM} / \mathrm{ha}$.

\section{NUE ratios}

Nitrogen use efficiency ratios based on $\mathrm{kg}$ DM/kg N applied are presented in Table 3 for the 2015 trials and Table 4 for the 2016 trials. The measured NUEs ranged from -3.3 to $31 \mathrm{~kg} \mathrm{DM} / \mathrm{kg} \mathrm{N}$ applied across all trials, products and rates.

Large $(\mathrm{P}<0.05)$ increases in NUE for Smartfert
Figure 4 Marginal pasture nitrogen concentrations ( $N \%$ )

Table 3 The nutrient use efficiency (NUE) ( $\mathrm{kg} \mathrm{DM} / \mathrm{kg} \mathrm{N}$ applied) 1 relative to the control of a single application of two rates of Sustain or Smartfert on two sites in 2015 .

\begin{tabular}{lcccccc}
\hline Site & & Sustain $\mathbf{3 0}$ & Sustain 60 & Smartfert30 & Smartfert 60 & SED \\
\hline Northland & NUE & 31 & 31 & 24 & 22 & 5.6 \\
Rotorua & NUE & -3.3 & 7.9 & 28 & 12 & 8.9 \\
\hline
\end{tabular}

Measured over 6 harvests.

Table 4 The nutrient use efficiency (NUE) ( $\mathrm{kg} \mathrm{DM} / \mathrm{kg} \mathrm{N}^{2}$ applied) ${ }^{1}$ relative to the control of a single application of Sustain or Smartfert at $30 \mathrm{~kg} \mathrm{~N} / \mathrm{ha}$, a single application of Smartfert at $100 \mathrm{~kg} \mathrm{~N} / \mathrm{ha}$ and a multiple (3x) application of Sustain at 33 $\mathrm{kg} / \mathrm{ha}$ on three sites in 2016 .

\begin{tabular}{lcccccc}
\hline Site & Sustain $\mathbf{3 0}$ & Smartfert30 & Sustain 33×3 & Smartfert 100 & SED \\
\hline Northland & 4.5 & 4.5 & 11.3 & 13.5 & 6.9 & \\
Rotorua & 5.8 & 7.5 & 10.9 & 10.1 & 4.7 & \\
Canterbury & 2.4 & 22 & 5.3 & 17.8 & 12.9 & \\
\hline
\end{tabular}

Measured over 6 harvests.
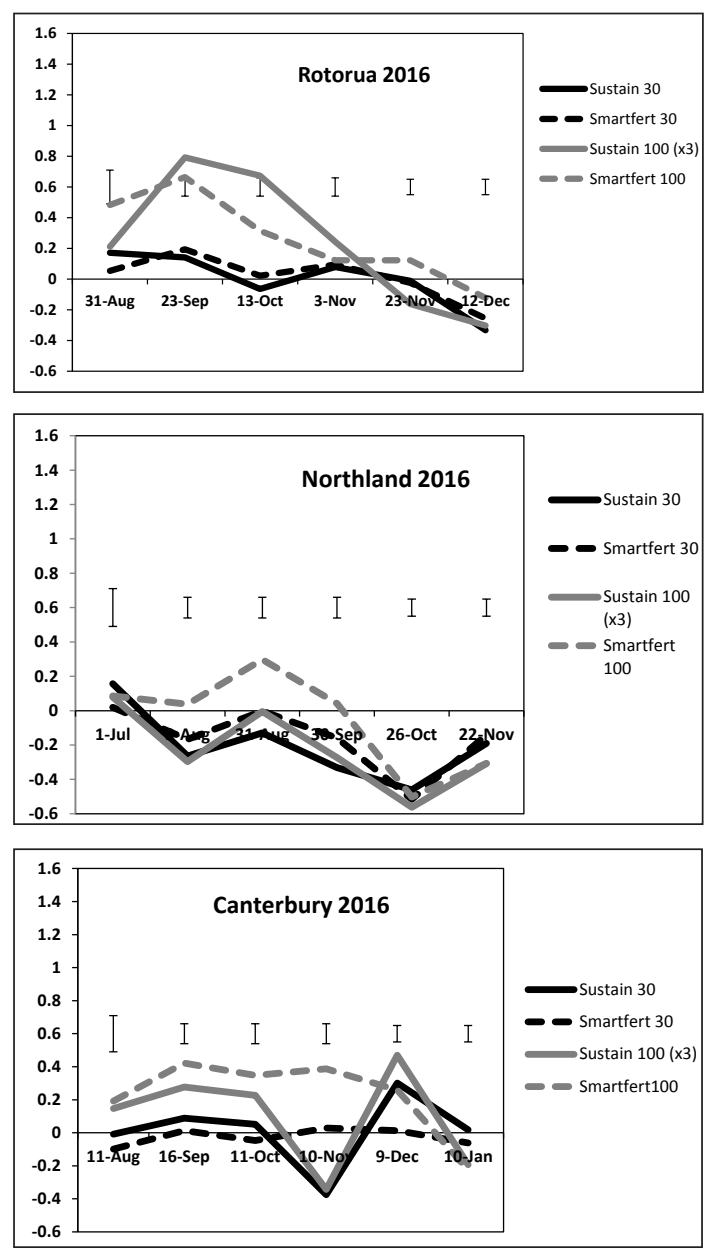

Figure 5 Marginal pasture nitrogen concentrations (No) relative to control over time after single applications of Sustain and Smartfert (30 kg N/ha) and Smartfert (100 kg N/ha) and split applications of Sustain $(3 \times 33 \mathrm{~kg} \mathrm{~N} / \mathrm{ha})$ in three trials in 2016. Vertical bars are the SED's assuming the same

pasture $\mathrm{N}$ concentrations and hence $\mathrm{N}$ leaching. Further pearch however, is required to define the condition where these benefits can be confidently captured, noting that the motivation for these trials was driven by commercial rather than scientitifc considerations. It is for this reason no site specific soil or meterological data were collected to assist with deciding the reasons for the different size and patterns for the pasture responses to either SustaiN or Smartfert between the various experiments.

\section{ACKNOWLEDGEMENTS}

This research was funded by Ballance AgriNutrients Ltd who market Smartfert under their brandname StrategN. Technical assistance with the field trial by Sarah Anderson, Duncan Bayne and Peter Carey is appreciated and acknowledged. We thank Dr Mark Shepherd (AgResearch) for useful discussions and for the use of his as yet unpublished desktop calculator for estimating the effect of pasture $\mathrm{N}$ concentrations of the amount of $\mathrm{N}$ leached.

Disclosure: The author was retained as a science advisor by Eko360 Ltd, a New Zealand based company licenced to market SmartFert, and has no pecuniary interest in this company or Ballance AgriNutrients Ltd.

\section{REFERENCES}

Carlson, W.T.; Lucci, G.L.; Sprosen, M.S. Response of pastures to fertiliser nitrogen on two peat soils in the Waikato region. Journal of New Zealand Grasslands 79: 79-82.

de Klein, C.A.M.; Monaghan, R.M.; Alfaro, M.; Gourley, C.; Oenema, O.; Powell, J.M. 2016. Relalistic nitrogen use efficiency goals in dairy produciton systems: a review and case study examples. Proceedings of the 2016 International Nitrogen Initiative Conference. Solutions to improve nitrogen use efficiency for the world. Melbourne, Australia. www.ini2016.com

Dijkstra, J.; Oenema, O.; van Groenigen, J.W.; Spek, J.W.; van Vuuren, M.A.; Bannink, A. 2013. Diet effects on urine composition of cattle and $\mathrm{N}_{2} \mathrm{O}$ emissions. Animal 7: 292-302

relative to SustaiN were recorded in the 2015 Rotorua and the 2016 Canterbury trials at $30 \mathrm{~kg} \mathrm{~N} / \mathrm{ha}$. A large but not statistically significant increase in NUE was recorded for Smartfert 100 relative to SustaiN ( 3 x $33 \mathrm{~kg} \mathrm{~N} / \mathrm{ha}$ ) in the 2016 Canterbury trial. In comparison, Edmeades (2015) reported increases in NUE for Smartfert of between $5-50 \%$ in three earlier trials, but none of these effects were statistically signficant. These increases in NUE for Smartfert suggest the N lossess via leaching, volatilisation and denitrification are less than from urea.

\section{Conclusions}

The results suggest that Smarfert can be used to reduce fertiliser $\mathrm{N}$ application costs by reducing the number of applications of soluble $\mathrm{N}$ fertiliser and/or reducing
D.C.; McBride, R.M. 2012. Evaluating the agronomic effectiveness of fertiliser products Proceedings of the New

Edmeades, D.C. 2015. The evaluation of a controlled release nitrogen fertiliser. Journal of New Zealand Grasslands 77: 147-151.

Feyter, C.; O'Connor, M.B.; Addison, B. 1985. Effects of rates and times of nitrogen application on the production and composition of dairy pastures in the Waikato district, New Zealand. New Zealand Journal of Experimental Agriculture 13: 247-252. 
Lynch, P.B. 1966. Conduct of Field Experiments. Bulletin No. 399. New Zealand Department of Agriculture

Ministry for Primary Industries. 2013. Nutrien Management Science - State of Knowledge, Use an Uptake in New Zealand. MPI Technical Paper No 2013/59.

Our Nutrient World. 2013. The Challenge to Produce More Food and Energy with Less pollution. Accessed: 17/4/2015. http://www.initrogen.org/publ_panel
Roberts, A.; Morton, J. 2004. Fertiliser use on New Zealand dairy farms. New Zealand Fertiliser Manufacturer's Research Association. Auckland, New Zealand.

Shepherd, M.; Lucci, G. 2013. A review of the effect of autumn nitrogen fertiliser on pasture nitrogen concentration and an assessment of the potential effects on nitrate leaching risk. Proceedings of the New Zealand Grassland Association 75: 197-202.

\section{Response of pastures to fertiliser nitrogen on two peat soils in the Waikato region}

W.T. CARLSON, G.L. LUCCI and M.S. SPROSEN AgResearch Ruakura, Private Bag 3123, Hamilton 3240, New Zealand

\section{Abstract}

Fertiliser nitrogen $(\mathrm{N})$ response trials were conducted on Waikato dairy pastures on two contrasting peat soils: a well-developed Kaipaki peat loam and a lessdeveloped Rukuhia peat. On the well-developed site the most efficient $\mathrm{N}$ fertiliser rate in spring was $25 \mathrm{~kg} \mathrm{~N} /$ ha with a response of $22 \mathrm{DM} / \mathrm{kg} \mathrm{N}$ applied. However, in autumn the most efficient rates of $\mathrm{N}$ fertiliser were 75 and $100 \mathrm{~kg} \mathrm{~N} / \mathrm{ha}$, with an average response rate of $11 \mathrm{~kg} \mathrm{DM} / \mathrm{kg} \mathrm{N}$. At the less-developed site, the most efficient rates in the spring were 25 to $75 \mathrm{~kg} \mathrm{~N} / \mathrm{ha}$ with an average response of $18 \mathrm{DM} / \mathrm{kg} \mathrm{N}$ applied. In autumn, the maximum response rate of $21 \mathrm{~kg} \mathrm{DM} / \mathrm{kg} \mathrm{N}$ was reached through application of 50 and $75 \mathrm{~kg} \mathrm{~N} / \mathrm{ha}$. Results indicate that greater yields are expected from larger applications of $\mathrm{N}$ fertiliser on less-developed peat. However, the environmental consequences of increased $\mathrm{N}$ fertiliser applications have not yet been assessed.

Keywords: nitrogen fertiliser, pasture production, peat

\section{Introduction}

There are around 94000 ha of peat (organic) soils in the Waikato with $80 \%$ of the area developed fo agriculture (O'Connor et al. 2001). The properties of peat soils (e.g. carbon content, $\mathrm{pH}$, and water holding capacity) change with development stage from raw to consolidated forms due to drainage and cultivation; developed peat has a higher bik densty cons organic matter and al. 2006), OConnor etal. (2001) used the development state of organic soils to develop guidelines for fertiliser applications of phosphate, potassium and sulphur. However, there have been few studies in New Zealand on the response of pastures on peat soils to $\mathrm{N}$ fertiliser, and in particular how the stage of development might affect response (van der Elst 1980; Baars et al. 1989) values in mineral soils explain some of the variation in pasture response to $\mathrm{N}$ fertiliser (Shepherd et al. 2015), but it is unclear if this relationship holds for peat soils. Spring and autumn field studies on two peat soils of differing development status were commenced in August 2015. The objective was to determine which rates of $\mathrm{N}$ fertiliser produced the most efficient pasture response on peat soils.

\section{Methods}

\section{Trial location}

The two experimental sites in the Waikato region, north of Hamilton, were selected to represent contrasting pea soils used for dairy farming. The well-developed (WD) site was on a Kaipaki peat in an area that was developed for farming in the 1890s. The soil had a high anion storage capacity (ASC) and Olsen P status (Table 1). The less-developed (LD) site was on a Rukuhia peat, in Canded for farming in the 197 ASC and a moderate P status (Table 1). Both sites were on well established, intensively grazed ryegrass/white clover pastures with low bulk density and high total carbon, compared with mineral soils. Before the start of the trial, soil measurements were taken to characterise the sites (Table 1).

\section{Trial design and management}

The experimental design at both sites and seasons consisted of: 5 treatments $\mathrm{x} 5$ replicates arranged in a andomised block design. The treatments were: 0,25 , 50,75 and $100 \mathrm{~kg} \mathrm{~N} / \mathrm{ha}$, applied as granular urea to 1.5 $\mathrm{x} 4 \mathrm{~m}$ plots. A single urea application was followed by 3 pasture harvests. The spring and autumn trials were in separate nearby areas.

Basal fertiliser was applied to both spring and autumn

Table 1 Soil properties of the 2 sites $(0-15 \mathrm{~cm}$ depth). Samples were analysed for $\mathrm{pH}$, Olsen phosphorus (P), potassium (K) sulphur (S), anion storage capacity (ASC), total nitrogen (TN), total carbon (TC) and bulk density (BD).

\begin{tabular}{|c|c|c|c|c|c|c|c|c|c|}
\hline \multirow[t]{2}{*}{ Site } & \multirow[t]{2}{*}{$\mathrm{pH}$} & \multirow{2}{*}{$\begin{array}{c}\mathbf{P} \\
(\mu \mathrm{g} / \mathrm{ml})\end{array}$} & \multirow{2}{*}{$\begin{array}{c}\mathbf{K} \\
\text { (QT) }\end{array}$} & \multirow{2}{*}{$\begin{array}{l}\mathbf{S}\left(\mathrm{SO}_{4}\right) \\
(\mathrm{ppm})\end{array}$} & ASC & TN & TC & \multirow{2}{*}{$\begin{array}{l}\text { C:N } \\
\text { ratio }\end{array}$} & \multirow{2}{*}{$\begin{array}{c}\text { BD } \\
\mathrm{g} / \mathrm{cm}^{3}\end{array}$} \\
\hline & & & & & & (\%) & & & \\
\hline LD & 5.4 & 24 & 5 & 6 & 19 & 1.67 & 37.1 & 22 & 0.37 \\
\hline WD & 5.7 & 63 & 2 & 25 & 96 & 1.11 & 20.9 & 19 & 0.51 \\
\hline
\end{tabular}

